\title{
Promoting University Students' Collaborative Learning through Instructor-guided Writing Groups
}

\author{
Faustin Mutwarasibo ${ }^{1}$ \\ ${ }^{1}$ Department of Modern Languages, National University of Rwanda, Butare, Rwanda \& Department of Behavioural \\ Sciences and Learning, Linköping University, Linköping, Sweden \\ Correspondence: Faustin Mutwarasibo, Department of Modern Languages, National University of Rwanda, P.O.Box \\ 446 Butare, Rwanda. E-mail: mutfaust@yahoo.fr
}

Received: March 11, 2013

Accepted: April 1, 2013

Online Published: May 6, 2013

doi:10.5430/ijhe.v2n3p1

URL: http://dx.doi.org/10.5430/ijhe.v2n3p1

\begin{abstract}
This paper aims to examine how to promote collaborative learning among university students via instructor-guided writing groups. The research took place in Rwanda and was undertaken as a case study involving 34 second year undergraduate students, divided into 12 small working groups and one instructor. The data were collected by means of open-ended group interviews carried out after each of the 12 groups had finished writing an essay in English. In their responses, students acknowledged having improved their interpersonal and collaborative skills through writing groups. Students also indicated that, while discussing and interacting with their group members and with the support from their instructor, they improved their English, gained new ideas and perspectives, and learned better about text coherence. However, a small section of students did not appreciate working in groups while writing due to occasional internal disagreements and incompatibility between group members. Some strategies are proposed on how an instructor can help make group work a relevant and effective learning tool.
\end{abstract}

Keywords: Collaborative learning, Group work, Group writing, Higher education, Instructor-guided writing groups, Rwanda

\section{Introduction}

Research in teaching and learning in various higher education contexts around the world highlights various learning benefits to be gained from group work (Barkley, Cross \& Major, 2005; Cavanagh, 2011; Griffiths, 2009). According to Frederick (1993), Hillyard, Gillespie and Littig (2010), frequent use of group work in the classroom is believed to enhance students' motivation, self-confidence, self-esteem and success. Other researchers assert that by working together, students are likely to learn to listen carefully, question, respect the opinions of others, share and collaborate which, by themselves, are of lifelong value (Hammond, Bithell, Jones \& Bidgood, 2010). For Christensen (2006); Johnson, Johnson and Smith (2007), Underwood (2003), Waite and Davis (2006), learning how to collaborate in groups is itself a form of knowledge.

Despite a multitude of benefits that students might gain from group work, some studies (e.g. Hensvold, 2006; Granström, 2006) have reported the reluctance of teachers to integrate group working methods in their classrooms. Other studies which support group work hold that some prerequisites ought to be in place for group work to be effective (Dobao, 2012; Hammar Chiriac, 2011). Among these prerequisites, students need to receive training on how to plan and practice group work (Fawcett \& Garton, 2005; Gillies, 2008). As it looks, a major responsibility in turning group work into a positive learning experience for students mainly rests with the course instructor (Hammar Chiriac, 2011; Hensvold, 2006; Mutwarasibo, 2013).

Group work can be applied to any course and any academic discipline. But for the present study, it was used in writing owing to the latter's potential to help improve teaching practices and stimulate learning (Wingate, Andon \& Cogo, 2011). In fact, researchers concur that writing is part of the learning process itself and is a mechanism for discovery and thinking (Coffin et al., 2003; Creme \& Lea, 2008; Gillett, Hammond \& Martala, 2009; Nightingale, 2000). Writing can also help students learn some generic skills which are desirable in professional life, among them, logical and critical thinking, problem-solving, communication, organizational and time management skills (Shields, 2010) and thus enhance their employability. It is worth stressing that these skills and competencies can be obtained while writing in any language. 
The common features among the studies carried out on group work and group writing are that they all highlight both benefits and controversies surrounding group-based learning as well as the role of the instructor in students' group operations. However, not much is mentioned about how the course instructor views his/her role in group formation, group support and follow up mechanisms. Neither do those studies show how the students view their instructor's role in their group work and what exactly they could expect from him/her. These are the main issues discussed in this study.

\section{Context and Motivation}

The study took place in Rwanda and reflects the context of change in the Rwandan higher education system (National Council for Higher Education [NCHE], 2007b). The researcher's interest in how to stimulate students to learn collaboratively via instructor-guided group work stemmed from the wave of educational reforms that have been taking place in Rwanda since 1994. Although group work has been an issue in academic research literature for decades and is a common way in which university students in various settings conduct their learning, it was only explicitly introduced in the Rwandan higher education system and given more impetus in 2007 with the advent of the Credit Accumulation and Modular Scheme (NCHE, 2007b). This implies that group work in the Rwandan higher education system is a new phenomenon which is still being explored. At the centre of the Rwandan modular scheme, there are generic learning outcomes to be attained by students at the end of a module or programme. Those outcomes follow a sequential and hierarchical progression from the less complex and less demanding to the most complex and most demanding ones. Among the most complex and most demanding of those outcomes there is the ability of students to work with their peers (NCHE, 2007b). Altogether, the National Learning, Teaching and Assessment Policy (NCHE, 2007a) advocates a teaching strategy based on participatory approaches including group work, focus group discussions, debates, panel discussions and peer tutoring, among others. Thus, there was a need to investigate how instructors and students are adjusting to instructor-guided group work as a new provision in the Rwandan higher education teaching and learning system. One survey on student satisfaction which slightly touches on that issue was carried out in 2012 in one prominent higher learning institution in Rwanda. Of 546 students involved, 42\% showed that they were not satisfied with the quality of learning support they were receiving from their instructors (National University of Rwanda/Centre for Instructional Technology, 2012). This students' dissatisfaction with the quality of learning support offered to them also motivated this study.

\section{Group Work as a Means to Develop Student Learning: Opportunities and Controversies}

Group work or group-based learning has its roots in the social constructivist theory, originally based on the work of Vygotsky (1978). According to this theory, learning is inherently a socially situated activity and is actively constructed when members of a community interact among themselves and with others. Applied to the classroom context, this interaction may happen between course instructors and students or among students through pair and group work.

The relevance of group work in student learning processes can be looked at from two main perspectives, namely the developmental perspective (Hammar Chiriac \& Hempel, 2008; Slavin, 1987, 1990) and the motivational perspective (Webb \& Palincsar, 1996; Slavin, 1987, 1990). The developmental perspective of group work posits that learning develops through interaction and discussion among students and through the way they work together to find solutions to the problems they experience (Hammar Chiriac, 2011). As for the motivational perspective of group work, student learning only improves based on the nature of incentives, rewards or goal structures brought about by group work (Webb \& Palincsar, 1996; Slavin, 1987, 1990).

Even though group work is generally regarded as a useful student learning tool, it can also become an object of controversy as some studies conducted in this area and in different contexts seem to conclude. For instance, in their extensive research on collaborative learning techniques in an American context, Barkley et al. (2005) show that while working together, some group members can work at different speeds, others may dominate the group while the rest can sometimes deviate from the discussion topic. In an Australian context, Davies (2009) outlines the difficulties of motivating all members in a large group to work together and contribute equally because of their differing degrees of individual commitment, different cultural and linguistic backgrounds as well as conflicting demands between self-interest and altruism. Davies (2009) adds other factors which can hamper the smooth running of group work, namely the type of task and its complexity, group members' roles, recognition and reward of individual and group efforts as well as incentives and penalties by the instructor. In a Swedish context, Hammar Chiriac (2011) also warns that the use of reward systems in group work could negatively affect the quality of student learning as learners may be attracted more to the reward than group assignment. 
For a group to work successfully, genuine collaboration among group members is needed. This may only be achieved when members devise one common goal, actively participate in all group tasks and strive to attain meaningful learning at the end of their work (Barkley et al., 2005; Tyson, 1998). Meaningful learning may include gaining new knowledge and thinking, new skills, new networks and new views or refreshing the existing ones (Dobao, 2012; Shimazoe \& Aldrich, 2010). According to Davis (1993), Mellor (2009), Millis and Cottell (1998), Shimazoe and Aldrich (2010), genuine collaboration may be better achieved when groups are kept relatively small, that is, three to four members each. Other researchers advise that ground rules be established, and strategies to monitor and reward individual and group efforts be communicated beforehand to all group members (Scott-Ladd \& Chan, 2008). In terms of collaborative writing, Storch (2005) recommends that such an activity be implemented with prior class preparation. All these proposals to make groups work effectively point to the crucial role to be played by the instructor in various group operations.

\section{Developing Student Learning through Group Writing}

Like in studies on group work in general, some studies on student writing groups (e.g. Dobao, 2012; Hirvela, 1999; Shehadeh, 2011; Storch, 2002, 2005) also suggest a positive effect on task performance and student learning. In a study conducted by Storch (2002) on the patterns of interaction among ten pairs of ESL students attending an Australian university, she found that language learning is likely to occur in pairs that are collaborating or that interact in an expert/novice relationship. In her subsequent study in the same context, Storch (2005) compared the texts produced in English on the same topic by individual learners and pairs. The texts were analyzed looking for fluency, grammatical accuracy and sentence complexity. Overall, it was noticed that individual writers tended to produce overly detailed texts while students working in pairs produced shorter but more grammatically accurate and linguistically complex texts. A similar study carried out by Shehadeh (2011) in a large university in the United Arab Emirates indicated that collaborative writing had an overall significant effect on students' ESL writing. This effect was significant for ESL content, organization and vocabulary. Elsewhere, a study by Dobao (2012) was carried out in a public university in the US by comparing ESL texts produced by individual learners, pairs and groups. The study also arrived at the conclusion that the texts written by the groups were more accurate not only than those written individually, but also than those written in pairs.

All the above findings suggest that group writing has more learning benefits than individual writing. However, in one of the studies mentioned above, it is reported that the idea of writing together was rejected by a small section of participants who still viewed writing as an individual activity (Storch, 2005). This lack of enthusiasm for group writing was justified by a lack of confidence in the group members' own language skills as well as fear to contradict one another. Another reason was that it became harder for the students to concentrate when they were involved in group writing (Storch, 2005).

Other researchers who investigated why students refused to engage in collaborative writing showed that, in large writing groups, there was a possibility of having increased collaboration among group members but also a risk of having members who choose to remain passive (Dobao, 2012). In research literature on group work, these passive members are also referred to as passengers, bystanders, free-loaders, free riders (Bourner, Hughes \& Bourner, 2001; Davies, 2009; Race, 2010) or hitchhikers (Millis \& Cottell, 1998). Apparently, the duty to discourage passive group members also calls upon the instructor's intervention.

\section{Role of Instructor in Group-based Learning}

In an effort to try to make group work successful, effective and enjoyable for learners, some form of guidance and support from an instructor is always needed (Cavanagh, 2011; Frederick, 1993; Hillyard et al., 2010; Hirvela, 1999; Scott-Ladd \& Chan, 2008; Shimazoe \& Aldrich, 2010; Storch, 2002, 2005; Wingate et al., 2011; Leach \& Zepke, 2011; Zepke \& Leach, 2010). More specifically, Frederick (1993) points out that it is ultimately the instructor's responsibility to motivate and actively involve learners in their learning. In the present study, the role of the instructor in shaping group work is particularly emphasized due to the often-held assumption that when students are working in groups, the instructor's presence is not so important since students know by themselves how to work in groups (Griffiths, 2009).

In general terms, the instructor's role in student group work is that of a guide or facilitator. For Frederick (1993) and Hensvold (2006), being a facilitator entails three things, namely setting up clear, simple and task oriented instructions; timing group work activities to be undertaken, and finally, arranging the time for all groups to report to class what they have achieved. This final public reporting is thought to enable students to learn from each other's similar or different arguments (Frederick, 1993; Race, 2010). Further developed, Griffiths (2009) claims that being a 
facilitator has more to do with preparing students on the nature and purpose of group work activities to be performed, setting up the guidelines to follow and specifying the learning outcomes to attain in the end.

While discussing different reasons which lead instructors and students to resist group work, Shimazoe and Aldrich (2010) also highlight the critical roles to be played by the instructor. These roles include among others, coordinating, guiding, monitoring and framing students' group activities as well as stimulating and encouraging interactions among them. According to the same authors, these interactions are likely to enable students to learn from their own individual activities and from one another, which can make groups work appropriately to the benefit of both instructors and students.

In view of the abovementioned controversies related to group work, group writing and the crucial role to be played by the instructor, this study was designed with the aim to examine how undergraduate university students in Rwanda reflect on instructor-guided writing groups as a way to promote their collaborative learning. Four questions were investigated: (1) What did students say they learned from instructor-guided writing groups? (2) How did the instructor view his role in student writing groups? (3) What additional support had the students wished to obtain from their instructor to improve their group writing?

\section{Methods}

\subsection{Research Site}

The study was conducted in one higher learning institution in Rwanda in 2009. The site was chosen for four main reasons: First of all, as a Rwandan researcher, it was very motivating to carry out research in the context he is familiar with. Second, the institution chosen for research has been the sole public higher learning institution for about 35 years and has thus spearheaded all reforms that have impacted the entire Rwandan higher education sector during all that period. Third, the institution remains the most prominent provider of public higher education in Rwanda in terms of the number of academic staff and students as well as the variety of programmes it offers. Fourth, among the most important reforms initiated by the institution, there was an introduction, in 2007, of Credit Accumulation and Modular Scheme (NCHE, 2007b), with an explicit emphasis on group-based learning and of which this study is a partial reflection. Thus, the researcher found it relevant to examine how university students, with support from their instructors, make sense of this newly-introduced learner-centred system in terms of collaborative learning.

\subsection{Participants and Ethical Considerations}

The participants were selected from a class originally composed of 58 second-year undergraduate students, who were enrolled in the discipline of Modern Languages. The choice of the discipline and the class level were motivated by the researcher's background in the teaching of English writing. The participants also included one instructor of Written English II module. All the participants share the same linguistic and cultural background as they speak Kinyarwanda as a native language and use both French and English as foreign languages. Roughly, students' proficiency level of English could be thought of as intermediate and upper intermediate.

Given that the research on instructor-guided writing groups was introduced in the middle of the Written English II module and was designed to take place in the classroom and only last 10 hours out of the 200 hours allocated to the whole module, students were free to be involved or not in the research part of the module. Those who chose not to participate could still concentrate on other academic duties. Owing to this laxity in research participation, only 34 students volunteered to participate. Other ethical considerations in terms of information on aims and outcomes of the study as well as assurance of confidentiality were observed. In this regard, students were assured of anonymity as they are referred to by using codes: Student groups bear Roman numerals from I up to XII while respondents bear number 1 up to 34 and are referred to as males (M) and females (F).

\subsection{Research Design, Data Gathering Procedures and Data Analysis}

The research was designed as a case study using qualitative methods. These methods were mainly based on open-ended interviews carried out in English with individual groups of students, one day after they had completed writing an argumentative essay. Essay writing was something that students were familiar with, but they were unfamiliar with instructor-guided writing groups. After interviewing the groups of students, another interview was held with the writing course instructor.

For 34 students to perform the writing task, the researcher's original intention was to divide them into small working groups, that is, 10 groups of three members each and one group of four members. However, after three participants freely decided to withdraw from research, the final group composition was eight groups of three members each, one group of four members and three pairs. In agreement between the researcher and the writing module instructor, no 
student was allowed to team with the classmate they usually work with in the classroom. The purpose of this reshuffle was to make all groups establish themselves afresh and avoid that students who are used to work together take on their 'usual' roles. The instructor was in a better position to come up with the expected group arrangement as he was quite familiar with his students. Apart from changing the students' usual sitting arrangements, no other criterion was considered for group composition.

After all groups were set up, they were given some guidelines to follow while working together on a 400 -word argumentative essay. Those guidelines mainly consisted of presenting students with explicit and systematic explanations on the purpose, intended audience, structure, organization and style of an argumentative essay (Hyland, 2003, 2007; Negretti \& Kuteeva, 2011; Wingate, 2012) as well as the criteria for assessment. To make the task easier, students were requested to propose topics related to current issues in the context of Rwanda, which were likely to provoke controversy. As the essay was going to be peer-evaluated by the groups of students themselves (the evaluation part is beyond the scope of this study), and for the sake of fairness, all of them were directed to work on one topic among many proposed. Most students preferred to discuss gender and equality in the Rwandan context and the specific topic was: Can women be equal to men in the Rwandan context?

To make sure that all group writing guidelines were adhered to, all scheduled writing sessions were carried out in one classroom in the presence of the instructor and the researcher. However, the instructor's role was not to impose what to do in groups and how, but rather to guide and assist students whenever it was needed. The researcher's regular presence in the classroom was also necessary to make sure that in-class group writing was being implemented as expected. To minimize his possible influence on student group writing, the researcher did not play any other role in the classroom except that of occasionally moving around in the classroom and watching students in action.

As mentioned in the previous section, classroom-based student group writing took about ten hours which were spread across five non-consecutive days, that is, two hours of classroom-based group writing per day. This was done to respect the timetable of other academic activities. After group writing, two days were spent to interview the students, group per group, on what they had gained from instructor-guided group writing and what additional support they would have wished to obtain from him. On a separate occasion, a ten-minute interview was also held with the instructor on how he had seen his role in student writing groups. The interviews with the groups of students were audio-recorded, each lasting 20 minutes on average (see Appendix I for interview guide). When analyzing the data, all audio-recorded interview responses were transcribed and arranged under similar categories. Data analysis was done thematically, that is, by looking at the four main themes that emerged from all interview responses and by selecting and quoting the most comprehensive and illustrative responses.

\section{Findings}

The analysis of findings focuses on the students' reported gains and dilemmas with the instructor-guided student writing groups and the perceived role of the instructor. The analysis also looks at students' reflections on what could have led their writing groups to be more effective.

\subsection{Students' Reported Gains from Writing Groups}

From the interview responses, 26 students out of $34(76 \%)$ indicated that they benefited in many ways from writing together. Under this theme, two sub-themes were found, namely student group writing as a means to develop interpersonal and social skills, and group writing as a means to build confidence in speaking and arguing in English.

\subsubsection{Student group writing as a means to develop interpersonal and social skills}

From the students' responses, it appeared that group writing was viewed as an opportunity to advance, exchange, share, listen to and value peer opinions. Some students expressed the view that group work not only encouraged them to talk in English and gave them room to communicate and even challenge their fellows' views, but also to accept being challenged. For example, student M5 mentioned that "during the group [writing] task, I have learned to express my ideas, but also listen to and value my fellows' ideas". The same opinion was held by student M15 who held that "what I have gained from this [group writing] exercise is daring to talk to my peers [in English] and accepting being challenged, listening to them, being flexible and accepting that my ideas don't always have to win".

In addition to improved interpersonal communication, the students felt that the smooth exchange between group members added to the group's cohesion, unity and strength, thus making the group rather look like a safe family: 
Working in groups of three was like being in a family. So this 'family' has supported me by allowing me to freely express my views [in English] and listen to their views. And even in case of diverging views, we discussed until we agreed on what to put on paper. (V: M11)

\subsubsection{Group Writing as a Means to Build Confidence and Increase Specific Knowledge in English}

For some students who revealed that they were already familiar with instructor-guided group work, the major assets of group-based learning were belief in self, confidence, personal growth and development, and specific knowledge improvement. These students felt they were empowered to become active, fully-fledged and successful group members: "with group work you are assured of mutual support and success. You exchange ideas, you learn to build solid arguments and you gain new vocabulary [in English]" (V: M12). Similarly, student M31 was happy to say that "in group, when you make a mistake [in spoken or written English], your fellows can correct you". Another student appreciated working together with peers because it opened up the possibility of airing varied and stronger views and completing the writing task in a shorter period of time:

Working together as a [writing] group was very good because we had different ideas, but these were put together to produce one thing that is richer and stronger. So working together while writing an essay is very beneficial because you generate many ideas at once, you think and move more quickly. (X: M25)

Given that English was used as a foreign language, students also acknowledged having had better opportunities to improve their English vocabulary:

When we were brainstorming and organizing ideas, we knew some terms in Kinyarwanda and French, but we couldn't immediately find the equivalences in English. Then we gave each other the task of checking up those terms in a dictionary. When we met in class for the next session, everybody had to tell the others what they had found. So we helped one another to learn the new terms in English. (VIII: M20)

The manner in which students learned to cope with their group writing was particularly emphasized in their responses. Through group writing, the process and structure of essay writing in English became much clearer to students: "I always do brainstorming, but the organization stage [of writing] has been a bit of a problem for me. But with my group, I have learned how to organize the ideas generated; things are clearer to me now" (IX: M24). Another student firmly argued that "with my group, I know from now on how exactly to move through the different steps of essay writing" (X: F3).

\subsection{Students' Reported Dilemmas with Writing Groups}

Despite a variety of opinions defending the multiple benefits that group work is thought to generate, a few voices (24\%) pointed out something different. Under this theme, two sub-themes were found: Intense disagreements and lack of genuine collaboration between group members, and tensions between group's and individual member's writing achievements vis-à-vis efficient time management.

\subsubsection{Intense Disagreements and Lack of Genuine Collaboration between Group Members}

For some students, writing together is likely to lead to interminable discussion and unending disagreements between group members. According to them, "group writing can sometimes create problems, especially when you are with students who enjoy discussion more than actual work" (XII: M29). Other students revealed that they shied away from genuine group work because they had found it very challenging to face up to the heated debates and intense disagreements that emerged from group work and were carried out in a foreign language (English). In their own words, they avowed that: "everyone [in our group] tried to develop their ideas first and then later on, we met in class and put them together" (VI: M14). The members of Group VIII experienced a similar situation: "working as a group was challenging. One could choose one word to use and others disagreed. So, we could come up with three different words for one thing and we could fail to agree on which one to use" (VIII: M19). One of the characteristics of effective group work is its potential to stimulate learning via negotiation. But in the three cases mentioned above, students seemed to be unaware of the learning that was taking place in such long discussions and sometimes heated debates, however difficult an agreement could be to achieve.

\subsubsection{Tensions between Writing Achievements and Efficient Time Management}

Amid a number of students, there were tensions resulting from failure to understand who, between a group and an individual member, was able to produce a richer, more accurate and more coherent text within a reasonable amount of time. To illustrate this, one student argued that "working together [while writing] is somehow good but 
time-consuming because we have to share our ideas and agree on what to write" (IV: M8) while another participant insisted that "I also prefer working with a group because it helps you generate and share many ideas in a short time" (VII: M17). But while these students disagree on the amount of time required by a group to accomplish a writing task, they both concur that the text produced by an individual tends to be less accurate than that of a group: "when you are writing alone you are likely to make some language mistakes that you are not aware of" (IV: M8) and "once you are on your own, it can take a lot of time and you may run out of arguments" (VII: M17).

That an individual may need more time than a group to find relevant arguments to complete a writing task was diametrically opposed by another student: "when you are writing alone, you move straight and you spend less time than when you are working with a group". He went on to indicate that, "had I been writing alone I would have used half of the time that our group has used" (VII: M15). This view was shared by another student who asserted that "when you are writing alone, you get few ideas, but you are quick to develop them" (IX: M22).

Other positions held by students on what a group can accomplish in writing in comparison with an individual member, still highlighted some tensions: "when you are writing together, you don't do things as quickly as when you are writing alone" (II: M4). However, the same student concluded that "when you are in a writing group, you have to participate and you should feel eager to do so".

From all of the statements above, students' comments indicate that they held quite contradictory views about the relevance of group writing. However, those contradictions, tensions and misunderstandings might disappear once clear and sufficient information is provided beforehand on what group work may encompass and what students might gain from it. As this study suggests, the person who is in a better position to play this role is the instructor. Under the next section, he explains how his role was performed.

\subsection{Instructor's Role in Student Writing Groups}

During the interview with the writing instructor, he explained how he had understood his role in student writing groups. Apart from the preliminary roles of designing the group writing task, setting up the guidelines and deciding on the composition of groups, the instructor argued that "students felt safe because they knew they were accompanied throughout the whole process of their group writing". More specifically, he showed that his support consisted of keeping track of what was being done in the classroom by the twelve writing groups, assisting to translate some culture-related terms and expressions from Kinyarwanda into English, and keeping the time for each classroom-based writing session.

\subsection{Students' Suggestions for Further Writing Development}

Owing to some difficulties and uncertainties noted during the activity of writing in groups, the students were requested to say what they thought could have helped them feel more confident with their writing. Among many suggestions made, those recurring more often included more instructor guidance and feedback on the written assignments, more classroom debriefing sessions, more group writing exercises, and more individual readings. Insisting on the paramount role of the instructor, one student requested that "for any writing task, instructors should provide as many explanations as possible and be closer to the students so that they provide support whenever it may be needed" (V: M10). Another student focused on obtaining more writing exercises and instructor feedback as a way to stimulate more collaboration between the students and their instructor, and thus make writing more enjoyable:

It would be better if students were given an opportunity to do many writing exercises. But these wouldn't make sense if instructors don't follow us up, if they don't correct us and provide whatever support we may need. If this collaboration between instructors and students is achieved, writing will be fun for us (IX: M23).

Even though the students seemed to place a major responsibility on their instructors when it comes to improving writing, they also acknowledged that they have a big role to play via collaboration: "while writing, students should put together their efforts and bear in mind that they gain a lot when they learn together" (X: F3). Students' role can also be fulfilled through individual readings: "I would just advise my classmates to read as much as they can and consult the writings and essays produced by other people to see how they managed" (VII: M17). Finally, the role of all kinds of interaction in the development of students' expression and thinking was stressed: "joining the debating clubs can be an opportunity to talk and gain some new ways of thinking" (IX: M24).

In summary, the findings from this research indicate that the majority of the students acknowledged having learned in various ways from instructor-guided student writing groups. But some problems were also raised in terms of intense disagreements and lack of genuine collaboration among group members and failure to discern what exactly a writing group can accomplish in comparison with an individual writer. 


\section{Discussion}

This paper has examined how instructor-guided student writing groups can help promote collaborative learning among university students. The research focused on second year undergraduate students in a Rwandan university. One added value from this research is that students acknowledged having understood what effective collaboration means and how relevant it is for their learning. As evidence, students admitted having improved their interpersonal and social skills through group writing. More specifically, students mentioned that they dared to talk, listen, question, value and tolerate adverse opinions.

Another added value from this research is that students recognized having gained specific knowledge in English writing, mainly content and style. In fact, while writing in groups, students argued that they learned new English vocabulary, new ideas and new perspectives, and how to arrange them. As a result, they were allegedly able to produce more complex and more coherent texts in English. However, students did not say much about how group writing helped them to be aware of and address English language mistakes. If anything, these were only pointed out by the instructor.

The findings also show that apart from the fundamental role of setting the stage for classroom-based group writing, the instructor played a key supporting role for all 12 writing groups involved. This included being available for all groups during their writing sessions to make sure they were doing the writing and offering language support (helping to translate culture-related terms from Kinyarwanda into English) whenever it was needed.

From the instructor's point of view, among the major difficulties still faced by students in their English writing, there was grammar (tense use, word choice and word order), text organization and coherence. From a small section of students, there were problems related to group cohesion (intense disagreements between group members) and failure to recognize the positive effects of group work. However, the study could not establish whether the students who failed to collaborate were also the ones who produced low quality written work. Neither was the study able to prove that students who collaborated well, absolutely produced a well organized, coherent and more accurate work. Correspondence between the nature of collaboration among group members and the quality of the text produced were beyond the scope of this study.

Finally, there was an issue of knowing if students would have expected any other instructor support to help them perform better in their group writing. Apparently, most of the students' responses threw the responsibility to the instructor as someone to guide them but also give them feedback to their written assignments. But other responses indicated that students actually share the responsibility by initiating individual readings and being involved in collaborative exchanges with other students.

Compared to other studies on group writing (Dobao, 2012; Shehadeh, 2011; Storch, 2002, 2005) this study has investigated the nature of student collaboration in a writing classroom by specifically looking at the type of learning that takes place when an instructor is involved. The findings show that some form of meaningful learning (Barkley et al., 2005) has indeed taken place through this instructor-guided student group writing. The presence of the instructor to guide group writing is also meaningful in the world outside the classroom. In professional contexts, for instance, we are often obliged to work under supervision and in teams with people we do not know and have probably never met.

Previous work on group writing has shown that, for different reasons, some students did not enjoy working in groups. Similarly, in this study, collaboration and team work spirit did not appear to be adopted effectively for a small section of students. But given the multiple learning benefits that group work is believed to generate, it makes sense to devise measures which enable students to fully exploit those benefits. Among these measures, Cavanagh (2011), Frederick (1993) and Wingate et al. (2011) show that it is quite possible and effective to integrate collaborative learning activities and active involvement opportunities into lectures. This practice is likely to help allay students' uncertainty about group work because it merges autonomous and collaborative learning (Zepke \& Leach, 2010). Alternatively, in order to change students' negative views on group work, Scott-Ladd and Chan (2008) propose that instructors initiate mixed-gender group work. As regards the composition of learning groups, Barkley et al. (2005) suggest that instructors ought to strive towards achieving heterogeneity by mixing students of different abilities and competencies.

Some students did not like group work because it allegedly led to long discussions and intense disagreements, which resulted into a waste of time. To dissipate their worries, Frederick (1993) proposes that group work instructions be clear, simple and task oriented. He adds that groups need to be given a sense of how much time is available for their work and that, at the end of it, all of them need to know what their peers have achieved. The advice to set clear 
instructions for group work to run smoothly was also supported by Hammond et al. (2010) and Hillyard et al. (2010) through their use of an explicit teaching concept: They suggest that individual instructors explain to students the purpose of using a particular group activity in their class. Altogether, some group rules may be established and group members' roles well defined in advance to mitigate possible internal disagreements among group members (Scott-Ladd \& Chan, 2008).

\section{Conclusion}

This study has highlighted the benefits of group work as a pedagogical tool capable of stimulating and facilitating students' collaborative and active learning. For this tool to be more relevant and effective, it is advisable to resort to small groups as a strategy to discourage passive group members. The use of mixed-gender and mixed-ability groups has also been suggested as another strategy which can help reduce the incompatibility between group members. However, due to male dominance in the sample used, it was impossible to obtain sufficient gender-representative views from students' groups. Besides, only participants from one academic discipline were involved in the study, thus limiting the possibility of having alternative perspectives from the students in other disciplines. Thus, the study would benefit from being extended to other cohorts and other disciplines where female and male students are equally represented.

\section{References}

Barkley, E.F., Cross, K.P., \& Major C.H. (2005). Collaborative learning techniques: A handbook for College Faculty. Danvers: Jossey-Bass.

Bourner, J., Hughes, M., \& Bourner, T. (2001). First-year undergraduate experiences of group project work. Assessment \& Evaluation in Higher Education, 26(1), 19-39. http://dx.doi.org/10.1080/02602930020022264

Cavanagh, M. (2011). Students' experiences of active engagement through cooperative learning activities in lectures. Active Learning in Higher Education, 12(1), 23-33. http://dx.doi.org/10.1177/1469787410387724

Christensen, G. (2006). Project groups: An analysis of subjectification mechanisms in group and project work at university level. Copenhagen: University of Copenhagen/Department of Media, Cognition and Communication.

Coffin, C., Curry, M.J., Goodman, S., Hewings, A., Lillis, T.M., \& Swann, J. (2003). Teaching academic writing: A toolkit for higher education. New York and London: Routledge.

Creme, P., \& Lea, M.R. (2008). Writing at university: A guide for students (3rd ed.). New York: Open University Press.

Davies, W.M. (2009). Groupwork as a form of assessment: Common problems and recommended solutions. Higher Education, 58(4), 563-584. Retrieved September 17, 2010, from http://www.springerlink.com/content/m1116382767q00v8/

Davis, B.G. (1993). Collaborative learning: Group work and study teams. Retrieved March 12, 2011, from http://teaching.berkeley.edu/bgd/collaborative.html

Dobao, A.F. (2012). Collaborative writing tasks in the L2 classroom: Comparing group, pair, and individual work. Journal of Second Language Writing, 21, 40-58. http://dx.doi.org/10.1016/j.jslw.2011.12.002

Fawcett, L.M., \& Garton, A.F. (2005). The effect of peer collaboration on children's problem-solving ability. British Journal of Educational Psychology, 75, 157-169. http://dx.doi.org/10.1348/000709904X23411

Frederick, P.J. (1993). Motivating students by active learning in the history classroom. Perspectives, 37(7). Retrieved December 12, 2011, from http://www.historians.org/perspectives/issues/1993/9310/9310TEC.cfm

Gillett, A., Hammond, A., \& Martala, M. (2009). Successful academic writing. London: Pearson Longman.

Gillies, R.M. (2008). Teachers' and students' verbal behaviours during cooperative learning. In R.M. Gillies, A. Ashman \& J. Terwel (Eds.), The teacher's role in implementing cooperative learning in the classroom (pp. 243-262). Brisbane: Springer. http://dx.doi.org/10.1007/978-0-387-70892-8_12

Granström, K. (2006). Group phenomena and classroom management in Sweden. In C.M. Evertson \& C.S. Weinstein (Eds.), Handbook of classroom management: Research, practice and contemporary issues (pp. 1141-1160). Mahwah: Lawrence Erlbaum Associates.

Griffiths, S. (2009). Teaching and learning in small groups. In H. Fry, S. Ketteridge, \& S. Marshall (Eds.), $A$ handbook for teaching and learning in higher education: Enhancing academic practice (3rd ed., pp. 72-84). New York and London: Routledge. 
Hammar Chiriac, E. (2011) Research on group work in education. New York: Nova Science Publishers.

Hammar Chiriac, E., \& Hempel, A. (2008). Handbook for group work: Establishing functioning group work in education. Lund: Studentlitteratur.

Hammond, J.A., Bithell, C.P., Jones, L., \& Bidgood, P. (2010). A first year experience of student-directed peer-assisted learning. Active Learning in Higher Education, 11(3), 201-212. http://dx.doi.org/10.1177/1469787410379683

Hensvold, I. (2006). Student active working models and learning in comprehensive school. Stockholm: The Authority for School Development.

Hillyard, C., Gillespie, D., \& Littig, P. (2010). University students' attitudes about learning in small groups after frequent participation. Active Learning in Higher Education, 11(1), 9-20. http://dx.doi.org/10.1177/1469787409355867

Hirvela, A. (1999). Collaborative writing instruction and communities of readers and writers. TESOL Journal, 8(2), 7-12. http://dx.doi.org/10.1002/j.1949-3533.1999.tb00169.x

Hyland, K. (2003). Genre-based pedagogies: A social response to process. Journal of Second Language Writing, 12 , 17-29. http://dx.doi.org/10.1016/S1060-3743(02)00124-8

Hyland, K. (2007). Genre pedagogy: Language, literacy and L2 writing instruction. Journal of Second Language Writing, 16, 148-164. http://dx.doi.org/10.1016/j.jslw.2007.07.005

Johnson, D.W., Johnson, R.T., \& Smith, K. (2007). The state of cooperative learning in postsecondary and professional settings. Educational Psychology Review, 19, 15-29. http://dx.doi.org/10.1007/s10648-006-9038-8

Leach, L., \& Zepke, N. (2011). Engaging students in learning: A review of a conceptual organiser. Higher Education Research \& Development, 30(2), 193-204. http://dx.doi.org/10.1080/07294360.2010.509761

Mellor, A. (2009). Group work assessment: Benefits, problems and implications for good practice. Red Guide Paper 53. Retrieved March 13, 2011, from http://www.northumbria.ac.uk/static/5007/arpdf/academy/redguide53.pdf

Millis, B.J., \& Cottell, P.G. (1998). Cooperative learning for higher education faculty. Phoenix: Oryx Press.

Mutwarasibo, F. (2013). University students' conceptions and practice of collaborative work on writing. International Journal of Higher Education, 2(2), 13-21. http://dx.doi.org/10.5430/ijhe.v2n2p13

National Council for Higher Education (2007a). National learning, teaching and assessment policy. Kigali: Author.

National Council for Higher Education (2007b). Rwandan national qualifications framework for higher education. Kigali: Author.

National University of Rwanda/Centre for Instructional Technology (2012). Draft report on student satisfaction survey. Butare: Author.

Negretti, R., \& Kuteeva, M. (2011). Fostering metacognitive genre awareness in L2 academic reading and writing: A case study of pre-service English teachers. Journal of Second Language Writing, 20, 95-110. http://dx.doi.org/10.1016/j.jslw.2011.02.002

Nightingale, P. (2000). Improving student writing. In S. Makoni (Ed.), Improving teaching and learning in higher education: A handbook for Southern Africa (pp. 131-166). Johannesburg: Witwatersrand University Press.

Race, P. (2010). Making learning happen: A guide for post-compulsory education (2nd ed.). London: Sage.

Scott-Ladd, B., \& Chan, C.C.A. (2008). Using action research to teach students to manage team learning and improve teamwork satisfaction. Active Learning in Higher Education, 9(3), 231-248. http://dx.doi.org/10.1177/1469787408095848

Shehadeh, A. (2011). Effects and student perceptions of collaborative writing in L2. Journal of Second Language Writing, 20, 286-305. http://dx.doi.org/10.1016/j.jslw.2011.05.010

Shields, M. (2010). Essay writing: A student's guide. London: Sage Publications.

Shimazoe, J., \& Aldrich, H. (2010). Group work can be gratifying: Understanding and overcoming resistance to cooperative learning. College Teaching, 58, 52-57. http://dx.doi.org/10.1080/87567550903418594

Slavin, R.E. (1987). Developmental and motivational perspectives on cooperative learning: A reconciliation. Child Development, 58(5), 1161-1167. Retrieved March 29, 2013, from http://www.jstor.org/stable/1130612 
Slavin, R.E. (1990). Cooperative learning: Theory, research and practice. Englewoods Cliffs: Prentice-Hall.

Storch, N. (2002). Patterns of interaction in ESL pair work. Language Learning, 52(1), 119-158. http://dx.doi.org/10.1111/1467-9922.00179

Storch, N. (2005). Collaborative writing: Product, process, and students' reflections. Journal of Second Language Writing, 14, 153-173. http://dx.doi.org/10.1016/j.jslw.2005.05.002

Tyson, T. (1998). Working in groups (2nd ed.). Sydney: Macmillan Education.

Underwood, J.D.M (2003). Student attitudes towards socially acceptable and unacceptable group working practices. British Journal of Psychology, 94, 319-337. http://dx.doi.org/10.1348/000712603767876253

Vygotsky, L.S. (1978). Mind in society: The development of higher psychological processes. Cambridge, MA: Harvard University Press.

Waite, S. \& Davis, B. (2006). Collaboration as a catalyst for critical thinking in undergraduate research. Journal of Further and Higher Education, 30, 405-419. http://dx.doi.org/10.1080/03098770600965417

Webb, N.M., \& Palincsar, A.S. (1996). Group processes in the classroom. In D.C. Berliner, \& R.C. Calfee (Eds.), Handbook of educational psychology (pp. 841-873). New York: Macmillan.

Wingate, U. (2012). 'Argument!' Helping students understand what essay writing is about. Journal of English for Academic Purposes, 11, 145-154. http://dx.doi.org/10.1016/j.jeap.2011.11.001

Wingate, U., Andon, N., \& Cogo, A. (2011). Embedding academic writing instruction into subject teaching: A case study. Active Learning in Higher Education, 12(1), 69-81. http://dx.doi.org/10.1177/1469787410387814

Zepke, N., \& Leach, L. (2010). Improving student engagement: Ten proposals for action. Active Learning in Higher Education, 11(3), 167-177. http://dx.doi/org/10.1177/1469787410379680

\section{Appendix 1: Interview guide}

Interview with the students

1) What can you say you have learned from classroom-based group writing? Did writing in groups help you in any way? Any difficulties experienced? What kind of support did you get from your instructor?

2) What additional support would you have wished to obtain from your instructor?

Interview with the instructor

1) What kind of role(s) did you play in students' writing groups?

2) Do you feel that your presence in the classroom made any difference for students' writing groups? If yes, how? 